\title{
VEGETABLES \\ IN THE TROPICS
}

H.D. TINDALL

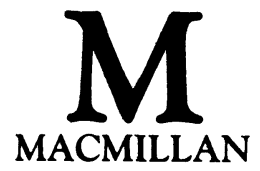


ISBN 978-0-333-24268-1 ISBN 978-1-349-17223-8 (eBook)

DOI 10.1007/978-1-349-17223-8

(C) Copyright text H.D. Tindall 1983

All rights reserved. No reproduction, copy or transmission of this publication may be made without written permission.

No paragraph of this publication may be reproduced, copied or transmitted save with written permission or in accordance with the provisions of the Copyright, Designs and Patents Act 1988, or under the terms of any licence permitting limited copying issued by the Copyright Licensing Agency, 90 Tottenham Court Road, London W1P 9HE.

Any person who does any unauthorised act in relation to this publication may be liable to criminal prosecution and civil claims for damages.

First published 1983

Reprinted 1987, 1988, 1992

Published by THE MACMILLAN PRESS LTD

London and Basingstoke

Associated companies and representatives in Accra,

Auckland, Delhi, Dublin, Gaborone, Hamburg, Harare,

Hong Kong, Kuala Lumpur, Lagos, Manzini, Melbourne,

Mexico City, Nairobi, New York, Singapore, Tokyo. 


\section{Contents}

List of Illustrations iv

Acknowledgements vii

Preface viii

Abbreviations $\quad$ ix

$\begin{array}{ll}\text { Introduction } & 1\end{array}$

Vegetables described in alphabetical order

of family, genus and species

Alliaceae, Amaranthaceae, Araceae,

Basellaceae, Chenopodiaceae,

Compositae, Convolvulaceae, Cruciferae,

Cucurbitaceae, Cyperaceae, Dioscoreaceae,

Euphorbiaceae, Gramineae, Labiatae,

Leguminosae, Liliaceae, Malvaceae,

Polygonaceae, Portula caceae,Solanaceae,

Tetragoniaceae, Tiliaceae, Umbelliferae

Select Bibliography

Appendix 1 Cultivars

Appendix 2 Pests

Diseases

Index of Species

Index of Common Names 


\title{
List of Illustrations
}

\author{
ALLIACEAE \\ Allium cepa var. aggregatum (Shallot) $17,18,19$ \\ Allium cepa var. cepa (Onion) 23 \\ Allium fistulosum (Welsh Onion) and Allium schoenoprasum (Chives) 25 \\ Allium fistulosum 26 \\ AMARANTHACEAE \\ Amaranthus caudatus (Quinoa) 37 \\ Amaranthus cruentus (Amaranth) 39 \\ Amaranthus tricolor (Chinese Spinach) 40, 41 \\ Celosia argentea (Cock's Comb) 42, 43 \\ ARACEAE \\ Colocasia esculenta (Cocoyam) 54 \\ Cyrtosperma chamissonis (Swamp Taro) 57 \\ Xanthosoma sagittifolium (Tannia) 60 \\ BASELLACEAE \\ Basella alba (Ceylon Spinach) $\quad 68,70$ \\ Ullucus tuberosus (Ulluco) 72 \\ CHENOPODIACEAE \\ Beta vulgaris var. cicla (Swiss Chard) 75 \\ Beta vulgaris subs. vulgaris (Beetroot) 78 \\ COMPOSITAE \\ Cichorium endivia (Endive) 83 \\ Helianthus tuberosus (Jerusalem Artichoke) 86 \\ Lactuca sativa (Lettuce) 91
}


CONVOLVULACEAE

Ipomoea aquatica (Kang Kong) 98

Ipomoea batatas (Sweet Potato) 101

CRUCIFERAE

Brassica chinensis (Chinese Cabbage) 110, 112

Brassica juncea (Leaf Mustard) 115

Brassica oleracea var.gongylodes (Kohlrabi) 124, 125

Brassica oleracea var. italica (Sprouting Broccoli) 127

Nasturtium officinale (Watercress) 132

Raphanus sativus (Radish) and Lycopersicon lycopersicum (Tomato) 136

Raphanus sativus var. longipinnatus (Chinese Radish) 136

CUCURBITACEAE

Benincasa hispida (Wax Gourd) 148

Coccinia cordifolia (Ivy Gourd) 153

Cucumis anguria (West Indian Gherkin) 155

Cucumis melo (Melon) 157

Cucurbita maxima (Squash Gourd) 163

Cucurbita moschata (Pumpkin) 167

Lagenaria siceraria (Bottle Gourd) 172

Luffa acutangula (Angled Loofah) 175

Luffa cylindrica (Smooth Loofah) 177

Momordica charantia (Bitter Gourd) 180

Sechium edule (Choyote) 183

Trichosanthes cucumerina (Snake Gourd) 188

DIOSCOREACEAE

Dioscorea alata (Water Yam) 204, 206

Dioscorea bulbilfera (Potato Yam) 208

EUPHORBIAC.AE

Manihot esculenta (Cassava) 227

LABIATAE

Coleus parviflorus (Sudan Potato) 241

Plectranthus esculentus (Livingstone Potato) 242

LEGUMINOSAE

Arachis hypogaea (Groundnut) 253

Canavalia ensiformis (Jack Bean) 258

Lablab niger (Hyacinth Bean) 269

Pachyrrhizus erosus (Yam Bean) 273

Phaseolus calcaratus (Rice Bean) 276 
Phaseolus lunatus (Lima Bean) 279

Psophocarpus tetragonolobus (Winged Bean) 287

Vigna unguiculata subsp. sesquipedalis (Asparagus Bean) 297

Voandzeia subterranea (Bambara Groundnut) 300

MALVACEAE

Hibiscus esculentus (Okra) 326

Hibiscus manihot (Sunset Hibiscus) 329, 330, 331

POLYGONACEAE

Rheum rhaponticum (Rhubarb) 340

PORTULACEAE

Talinum triangulare (Waterleaf) 343,345

SOLANACEAE

Capsicum annuum (Capsicum) 348, 349, 350

Capsicum frutescens (Hot Pepper) 353

Solanum macrocarpon (Local Garden Egg) 364

Solanum melongena (Egg Plant) 366

Solanum tuberosum (Irish Potato) 376

TETRAGONIACEAE

Tetragonia tetragonioides (New Zealand Spinach) 389

TILIACEAE

Corchorus olitorius (Long-fruited Jute) 393, 394

UMBELLIFERAE

Apium graveolens (Celery) 400

Coriandrum sativum (Coriander) 405

Foeniculum vulgare (Fennel) 410 


\section{Acknowledgements}

The publication of this handbook has only been possible due to the assistance I have been given in the compilation and preparation of the manuscript by many people and I wish to record my sincere thanks for their invaluable efforts.

I would particularly like to express my appreciation to the Rockefeller Foundation for the award of a study grant which enabled me to spend some time at the Villa Serbelloni in Italy. During this period I was able to plan and prepare the first draft of the handbook, which provided the essential basis for the later development of the text.

The data on pests and diseases were abstracted and compiled by Susan Carr and her contribution to this section of the handbook is sincerely appreciated.

All the drawings were prepared by Joanne Clark to whom I am indebted for her excellent work. The information on seed production was kindly provided by Ray George of the University of Bath and the nutritional data and cultivar lists were prepared by Gillian Ashburner.

I would like to express my sincere thanks to Professor J.P. Hudson for reading parts of the manuscript and for his valuable comments.

H.D. Tindall

Silsoe College

(Cranfield Institute of Technology)

Silsoe, Bedford, England 


\section{Preface}

The main objective of this handbook is to provide information on vegetable crops grown in the tropics which can be applied in practice. The increasing populations of many tropical countries have led to a new awareness of the importance of vegetable crops as a source of food, accompanied by the realization that many vegetables can supply essential nutritional materials which may not be readily available from other sources.

In addition to practical information on crop production, further details are given to provide a more comprehensive understanding of some of the related scientific principles described. Much of the information on various groups of crops should help readers to understand the relation between cultural requirements of closely-related species.

Significant technological advances have been made in recent years which can lead to increased efficiency of vegetable production in many parts of the world, but some notable advances in plant breeding, plant propagation, soil fertility improvement, irrigation practices, crop protection, mechanization and postharvest technology can only be applied in limited areas. Traditional and labourintensive practices are still of primary importance elsewhere in the tropics, where new and desirable technological developments can only be adopted if other resources become available.

These resources include the provision of all-weather roads for the transport of produce to local or regional markets, assistance with marketing through co-operative organizations, and the construction of dams or other means of providing water for irrigation. Most of these resources can only be supplied through appropriate government agencies. An effective extension service can assist the grower in obtaining some of the basic materials he requires to improve his efficiency but some essential items such as tools, seeds, fertilizers and pesticides are normally available only from commercial sources and the producer may find his activities limited until these become fully developed.

The handbook is intended to provide a comprehensive account of the principles and practices currently in use, so that students, vegetable growers, extension officers, research workers and administrators can appreciate the potential which exists for increasing the production of vegetable crops in tropical regions. 


\section{Abbreviations}

\begin{tabular}{|c|c|c|c|}
\hline Afr. & $\operatorname{Africa}(\mathrm{n})$ & $\mathrm{kg}$ & kilogramme \\
\hline Amer. & America & Lat.Amer. & Latin America \\
\hline Arg. & Argentina & & metre \\
\hline As. & Asia & Mal. & Malaysia \\
\hline Aus. & Australia & Mex. & Mexico \\
\hline Bangl. & Bangladesh & $\mathrm{mm}$ & millimetre \\
\hline Bol. & Bolivia & $\mathrm{N}$. & North \\
\hline Braz. & Brazil & Neth. & Netherlands \\
\hline C. & Central & Nig. & Nigeria \\
\hline Carib. & Caribbean & Pacif. & Pacific \\
\hline Chin. & China & Pak. & Pakistan \\
\hline Col. & Colombia & Pap.N.Guin. & Papua New Guinea \\
\hline $\mathrm{cm}$ & centimetre & Philipp. & Philippines \\
\hline C.Rica & Costa Rica & Polyn. & Polynesia \\
\hline $\operatorname{cv}(s)$ & cultivar(s) & P.Rico & Puerto Rico \\
\hline E. & East & S. & South \\
\hline Ecu. & Ecuador & Sen. & Senegal \\
\hline Egy. & Egypt(ian) & Sol. & Solomon \\
\hline Eng. & English & Sp. & Spanish \\
\hline Eth. & Ethiopia & Sri La. & Sri Lanka \\
\hline FAO & Food and Agriculture & subsp. & subspecies \\
\hline & Organization & Sud. & Sudan \\
\hline Fr. & French & Swah. & Swahili \\
\hline Ger. & German & Tanz. & Tanzania \\
\hline Gha. & Ghana & t/ha & tonnes per hectare \\
\hline Guy. & Guyana & Thai. & Thailand \\
\hline ha & hectare & Trin. & Trinidad \\
\hline Haw. & Hawaii & trop. & tropical \\
\hline Ind. & India & Ug. & Uganda \\
\hline Indon. & Indonesia & var. & variety \\
\hline Is. & Island(s) & Venez. & Venezuela \\
\hline Jam. & Jamaica & W. & West \\
\hline Jap. & Japan & W.I. & West Indies \\
\hline
\end{tabular}

